\title{
Convenient Synthetic Method for 3-(3-Substituted indol-2-yl)quinoxalin-2- ones as VEGF Inhibitor
}

\author{
Katsuyuki Aoki, ${ }^{*, a, c}$ Jyun-ichi Koseki, ${ }^{a}$ Shuichi TaKedA, ${ }^{a}$ Masaki AbUradA,${ }^{b}$ and \\ Ken-ichi Miуамото ${ }^{c}$ \\ ${ }^{a}$ Research Division, Tsumura \& Co.; 3586 Yoshiwara, Ami-machi, Inashiki-gun, Ibaraki 300-1192, Japan: ${ }^{b}$ Faculty of \\ Pharmacy, Musashino University; 1-1-20 Shinmachi, Nishitokyo, Tokyo 202-8585, Japan: and ${ }^{c}$ Department of Clinical \\ Pharmacy, Graduate School of Natural Science and Technology, Kanazawa University; 13-1 Takara-machi, Kanazawa, \\ Ishikawa 920-8641, Japan. Received December 26, 2006; accepted April 11, 2007; published online April 11, 2007
}

It has already been reported that 3-(indol-2-yl)quinoxalin-2-ones ${ }^{1)}$ have a potent inhibitory effect on the growth of tumor cells based on anti-angiogenesis activity. We have also carried out a structure-activity relationship (SAR) study of 3-(indol-2-yl)quinoxalin-2-ones, which showed a potent inhibitory activity toward the vascular endothelial growth factor (VEGF)-induced proliferation of human mesangial cells and the VEGF-induced auto-phosphorylation of human umbilical vein endothelial cells. ${ }^{2)}$ Moreover, one of these compounds has a potent medicinal effect based on anti-angiogenic action, by oral administration ${ }^{2)}$ (Chart 1, 9). However, since the existing synthetic methods ${ }^{1}$ for the preparation of 3-(indol-2-yl)quinoxalin-2-ones consist of multiple steps some of which require strict anhydrous conditions, a convenient and simple synthetic method in place of the existing method is desirable. As a result of the investigations into the synthetic procedures, 3-(3-substituted indol-2yl)quinoxalin-2-ones can be easily prepared by the condensation of 3-substituted indoles with quinoxalin-2-ones in the presence of trifluoroacetic acid (TFA). Herein, we report the examination of these reaction conditions and the application of this new synthetic method to the synthesis of the derivatives as VEGF inhibitors.

Key words indole; quinoxalin-2-one; trifluoroacetic acid; Friedel-Crafts reaction; vascular endothelial growth factor inhibitor

3-(Indol-2-yl)quinoxalin-2-ones has already been reported as an anti-angiogenesis agent by Ladouceur et al. ${ }^{1)}$ These compounds have a potent inhibitory effect on the growth of tumor cells with angiogenesis activity. We have also carried out a structure-activity relationship (SAR) study of 3-(indol2-yl)quinoxalin-2-ones, which showed a potent inhibitory activity toward the VEGF-induced proliferation of human mesangial cells and the VEGF-induced auto-phosphorylation of human umbilical vein endothelial cells. ${ }^{2}$ Moreover, these compounds have a potent medicinal effect based on anti-angiogenic action, by oral administration ${ }^{2)}$ (Chart 1,9$)$.

On the other hand, as shown in Chart 2, the two conventional synthetic method ${ }^{1)}$ of 3-(indol-2-yl)quinoxalin-2-ones

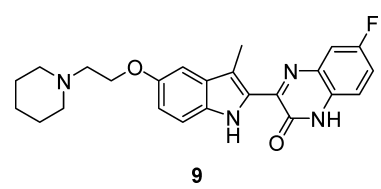

Chart 1. Structure of the VEGF Inhibitor 9
VI had been also reported. One of them is the A-route consisting of the crossing coupling of (indol-2-yl)boric acids with 2,3-dichloroquinoxalines. Another is the B-route in which (indol-2-yl)oxoacetate is condensed with phenylenediamine. In the case of the former, II was prepared by the reaction of I, which was protected at the 1-position of indole with a suitable protecting group, with a boric acid ester using an alkyl lithium reagent. Then III was prepared by the crossing coupling of II with 2,3-dichloroquinoxalines, which had previously been prepared separately. This route requires strict anhydrous conditions and low temperature. Moreover, two kinds of regioisomers of III might be generated by the coupling reaction of II with the substituted 2,3-dichloroquinoxalines. On the other hand, in the case of the latter route, the preparation of IV also needs strict anhydrous conditions and low temperature like A-route. In addition, $\mathrm{V}$ may be obtained as two different regioisomers by the reaction of IV with the substituted phenylenediamines. When more complicated derivatives are prepared for more extensive SAR studies, it could be expected that the number of steps would increase

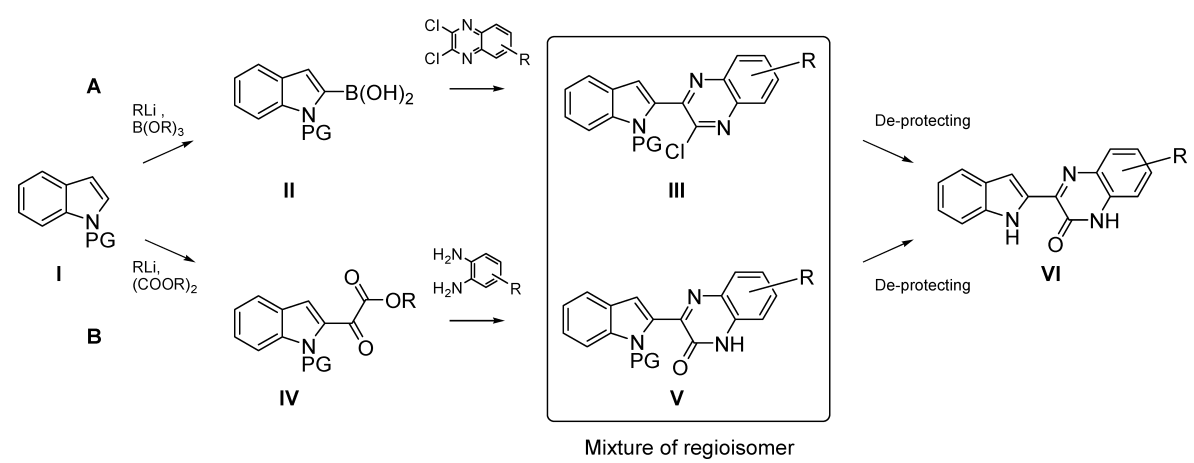

A: synthesis of framework via (indol-2-yl)boric acid. B: synthesis of framework via (indol-2-yl)oxoacetate. PG: protecting group.

Chart 2. Conventional Synthetic Method for 3-(Indol-2-yl)quinoxalin-2-ones ${ }^{1)}$ 
C

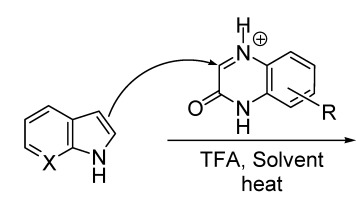

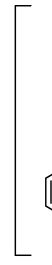
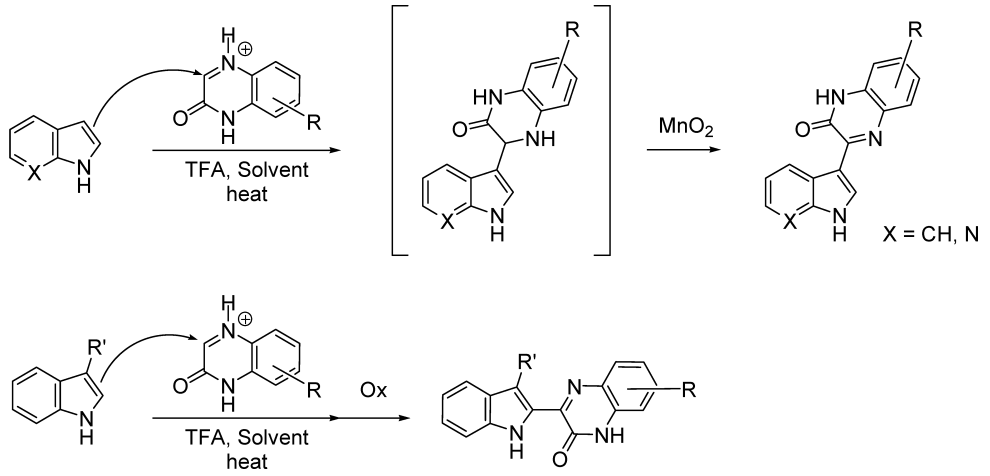

Chart 3. Reported Synthetic Method ${ }^{4)}$ for 3-(Indol-3-yl)quinoxalin-2-ones (C) and Our Strategy of Synthetic Method for 3-(Indol-2-yl)quinoxalin-2-ones (D)

Table 1. TFA-Catalyzed Coupling Reaction of 3-Substituted Indoles or Indole with Quinoxalin-2-one

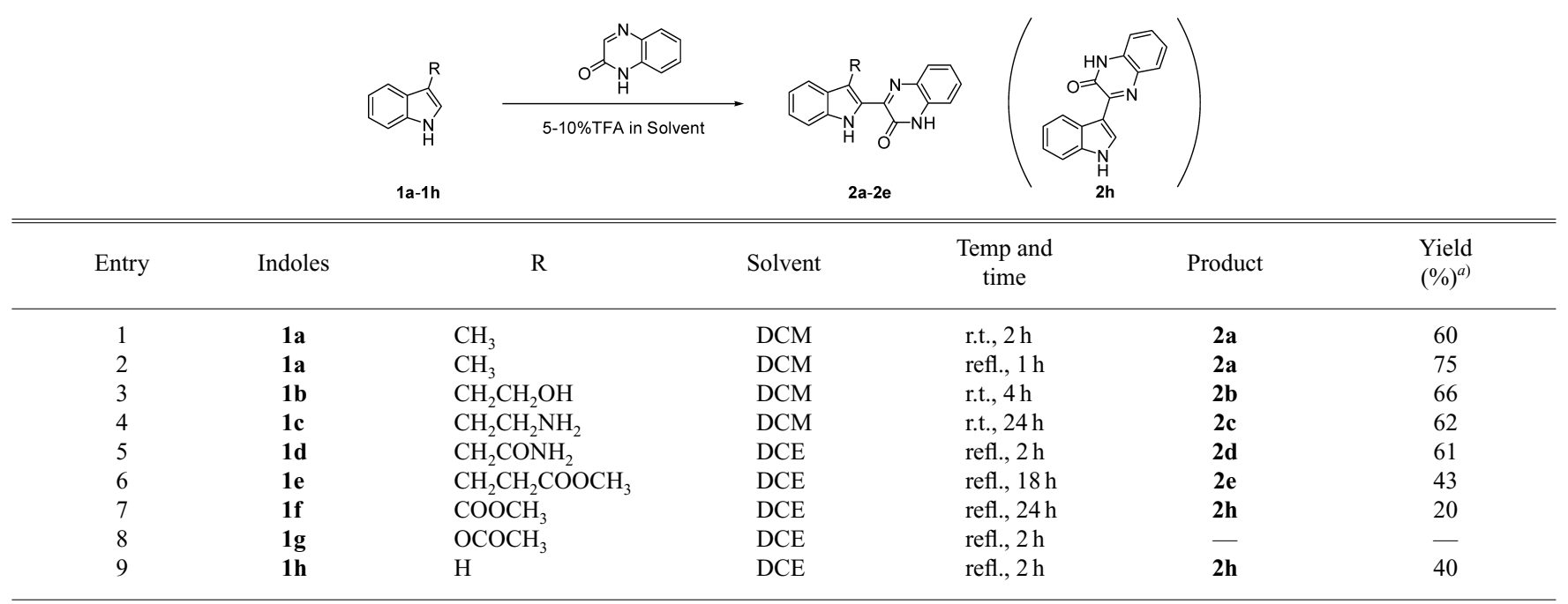

—: decomposition of indoxyl acetate. DCM: dichloromethane. DCE: 1,2-dichloroethane. These reaction conditions were not optimized. a) Isolated yield.

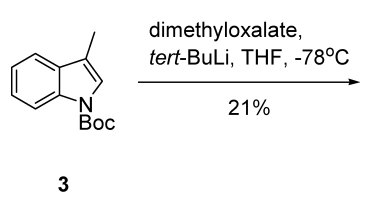

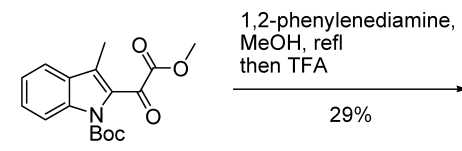

4

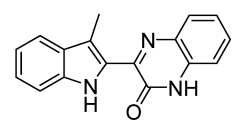

2a

Chart 4. Alternative Synthesis ${ }^{1)}$ of $\mathbf{2 a}$

because the protection and/or de-protection of intermediates are necessary in both routes. Therefore, a new and simple synthetic method, using highly regiospecific reactions and minimizing protection/de-protection steps as much as possible, was desired for the SAR study of these derivatives.

We have already reported the direct condensation ${ }^{3)}$ of indole or 7-azaindole with various substituted quinoxalin-2ones in the presence of TFA, which proceeds under mild conditions (Chart 3, C). In this reaction, the desired products are obtained by heating a mixture of indoles and quinoxalin-2ones in DMF in the presence of $10 \%(\mathrm{v} / \mathrm{v}) \mathrm{TFA}$, followed by treating with suitable oxidizers such as $\mathrm{MnO}_{2}$. Therefore, it was thought that the similar reaction ${ }^{4)}$ via the indolenine and/or direct pathway ${ }^{5)}$ of 3-substituted indoles with quinoxalin-2-ones might proceed and, as expected, the desired 3-(indolyl-2-yl)quinoxalin-2-ones can be prepared under these mild conditions (Chart 3, D).

\section{Chemistry}

Thus, the TFA-catalyzed condensation of $\mathbf{1 a}$ with quinoxalin-2-ones in dichloromethane (DCM) was actually carried out. As Table 1 shows, the reaction proceeded quite fast even at room temperature and afforded the desired product $\mathbf{2 a}$ in $60 \%$ of yield (Entry 1). In this TFA-catalyzed condensation, only the desired product was obtained by stirring a mixture of 3-methylindole and quinoxalin-2-one in DCM in the presence of $10 \%(\mathrm{v} / \mathrm{v})$ TFA, followed by a certain oxidation ${ }^{6}$ in situ, without generating any saturated side products, ${ }^{3)}$ unlike that observed in $\mathbf{C}$ (Chart 3). The structure of 2a has been determined by alternative synthesis employing the similar process, ${ }^{1)}$ as depicted in Chart 4 . The various 3 -substituted indoles react with quinoxalin-2-ones in DCM or 1,2dichloroethane (DCE), and the reaction is compatible with functional groups which are sensitive to strong base (see Table 1, Entry 3-6). Generally, the coupling reaction of in- 


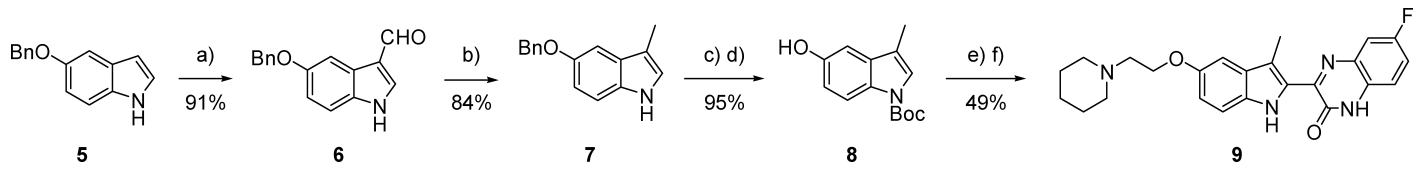

(a) acetic anhydride, imidazole, $130{ }^{\circ} \mathrm{C}$, (b) $10 \% \mathrm{Pd}-\mathrm{C}, \mathrm{NaBH}_{4}, 2-\mathrm{PrOH}$, refl., (c) $t$ - $\mathrm{Boc}_{2} \mathrm{O}, \mathrm{Et}_{3} \mathrm{~N}, \mathrm{DMAP}, \mathrm{CH}_{3} \mathrm{CN}$, r.t., (d) $\mathrm{H}_{2}, 10 \%$ Pd-C, AcOEt, r.t., (e) 1 - $(2$-chloroethyl)piperidine, $\mathrm{Cs}_{2} \mathrm{CO}_{3}, \mathrm{DMF}, 60^{\circ} \mathrm{C}$, (f) 6-fluoroquinoxalin-2-ones, TFA, DCE, refl.

Chart 5. Preparation of 9

doles bearing a substituent which raises the electron density on the ring tends to proceed promptly. However, in the case of $\mathbf{1 f}$, in which the electron density on the ring is lowered, an unexpected reaction accompanying decarobxylation proceeded to give $\mathbf{2} \mathbf{h}^{3,7)}$ in about $20 \%$ yield (Entry 7 ). The reaction of derivatives of $\mathbf{1 a}$, in which the indole was protected at 1-position with an electron withdrawing substituents such as a benzenesulfonyl group, ${ }^{8)}$ also failed. The TFA-catalyzed condensation of (3-indoxyl)acetate $\mathbf{1 g}$ with quinoxalin-2ones lead to decomposition of $\mathbf{1 g}$ (Entry 8). The reaction using the indole $\mathbf{1 h}$, which does not have a substituent at the 3-position, afforded only $\mathbf{2 h},{ }^{3,7)}$ in which substitution had taken place at the 3-position on the indole, in about $40 \%$ yield (Entry 9).

We then applied the new synthetic method to the preparation of a series of our VEGF inhibitors and give an example of their preparation here (Chart 5). The formylation of 5 using the method of Bergman ${ }^{9}$ afforded 6 in $91 \%$ yield. Then, the reduction ${ }^{10)}$ of 6 with $10 \% \mathrm{Pd}-\mathrm{C}$ and sodium tetrahydroborate in 2-propanol gave 7 in $84 \%$ yield. The protection of the 1-position on the indole ring of 7 by tert$\mathrm{Boc}_{2} \mathrm{O}$, followed by de-benzylation with $10 \% \mathrm{Pd}-\mathrm{C}$ in AcOEt under hydrogen atmosphere, provided 8 in $95 \%$ yield after 2 steps. The coupling reaction of $\mathbf{8}$ with 1-(2chloroethyl)piperidine in the presence of cesium carbonate $\left(\mathrm{Cs}_{2} \mathrm{CO}_{3}\right)$ in DMF, followed by the TFA-catalyzed condensation with 6-fluoroquinoxalin-2-ones, ${ }^{4)}$ easily provided 9 in reasonable yield without further purification. In this method, 9 could be prepared easily owing to the facile de-protection of tert-Boc under the TFA-catalyzed reaction condition.

In summary, we investigated a convenient and simple synthetic method for 3-(3-substituted indol-2-yl)quinoxalin-2ones and demonstrated a concise synthesis of $\mathbf{9}$, which may be a promising VEGF inhibitor. Moreover, since it is not necessary for our synthetic method to be carried out under strict anhydrous conditions and does not require special purification in the work-up process, it is likely that this reaction will be a very useful method in order to synthesize the concerned basic framework.

\section{Experimental}

The ${ }^{1} \mathrm{H}$ - and ${ }^{13} \mathrm{C}-\mathrm{NMR}$ spectra were measured with JEOL JNM-AL $(400 \mathrm{MHz})$ or JEOL EX-200 (200 MHz) spectrometer with TMS as the internal reference, and chemical shifts are expressed in $\delta(\mathrm{ppm})$. The HR-ESIMS was taken on a MICROMASS Q-Tof micro.

General Procedure for the Synthesis of 2a, 2b, 2c, 2d, 2e and 2h. 3-(3Methylindol-2-yl)quinoxalin-2-ones, 2a To a mixture of 3-methylindole $(65.5 \mathrm{mg}, 0.5 \mathrm{mmol})$ and quinoxalin-2-ones $(73.1 \mathrm{mg}, 0.5 \mathrm{mmol})$ in DCM $(2.5 \mathrm{ml})$ was added TFA $(0.2 \mathrm{ml})$ at room temperature, and then the reaction mixture was allowed to stir for $2 \mathrm{~h}$ at room temperature. The resulting reaction mixture was diluted with AcOEt, washed with saturated $\mathrm{Na}_{2} \mathrm{CO}_{3}$ aq., and the organic phase then dried over $\mathrm{Na}_{2} \mathrm{SO}_{4}$. After removing the organic solvent in vacuo, the residue was triturated in a small amount of $\mathrm{MeOH}$. The precipitated product was collected by filtration and washed with $\mathrm{Et}_{2} \mathrm{O}$ to give 2 a $(83.0 \mathrm{mg}, 0.30 \mathrm{mmol})$ as a yellow solid. Yield: $60.3 \%,{ }^{1} \mathrm{H}-\mathrm{NMR}$ $\left(400 \mathrm{MHz}, \mathrm{DMSO}-d_{6}\right) \delta: 2.77(3 \mathrm{H}, \mathrm{s}), 7.05(1 \mathrm{H}, \mathrm{t}, J=7.5 \mathrm{~Hz}), 7.20(1 \mathrm{H}, \mathrm{t}$, $J=7.5 \mathrm{~Hz}), 7.29-7.46(2 \mathrm{H}, \mathrm{m}), 7.51(1 \mathrm{H}, \mathrm{dt}, J=1.2,8.6 \mathrm{~Hz}), 7.63(1 \mathrm{H}, \mathrm{t}$, $J=7.5 \mathrm{~Hz}), 7.65(1 \mathrm{H}, \mathrm{d}, J=7.5 \mathrm{~Hz}), 7.83(1 \mathrm{H}, \mathrm{d}, J=8.5 \mathrm{~Hz}), 11.63(1 \mathrm{H}, \mathrm{s})$, $12.75(1 \mathrm{H}, \mathrm{brs}) .{ }^{13} \mathrm{C}-\mathrm{NMR}\left(100 \mathrm{MHz}, \mathrm{DMSO}-d_{6}\right) \delta: 11.56(\mathrm{~s}), 112.52(\mathrm{~s})$, $115.21(\mathrm{~s}), 115.97(\mathrm{~s}), 119.06(\mathrm{~s}), 123.65(\mathrm{~s}), 127.90(\mathrm{~s}), 128.14(\mathrm{~s}), 129.17$ $(\mathrm{s}), 129.48(\mathrm{~s}), 130.59(\mathrm{~s}), 132.51(\mathrm{~s}), 135.75(\mathrm{~s}), 148.34(\mathrm{~s}), 155.14(\mathrm{~s})$. ESIMS $m / z$ : +ESI $276(\mathrm{M}+1)$, -ESI $274(\mathrm{M}-1)$. HR-ESI-MS $m / z: 298.0963$ (Calcd for $\mathrm{C}_{17} \mathrm{H}_{13} \mathrm{~N}_{3} \mathrm{ONa}$ : 298.0956).

3-[3-(2-Hydroxyethyl)-1 $H$-indol-2-yl]quinoxalin-2(1H)-one, 2 b ${ }^{1} \mathrm{H}$ NMR $\left(400 \mathrm{MHz}\right.$, DMSO- $\left.d_{6}\right) \delta: 3.47(2 \mathrm{H}, \mathrm{t}, J=7.3 \mathrm{~Hz}), 3.73(2 \mathrm{H}, \mathrm{t}$ $J=7.3 \mathrm{~Hz}), 4.68(1 \mathrm{H}$, br s $), 7.05(1 \mathrm{H}, \mathrm{dd}, J=7.1,7.8 \mathrm{~Hz}), 7.20(1 \mathrm{H}, \mathrm{dd}$, $J=7.8,9.0 \mathrm{~Hz}), 7.33-7.40(2 \mathrm{H}, \mathrm{m}), 7.53(1 \mathrm{H}, \mathrm{t}, J=8.0 \mathrm{~Hz}), 7.63(1 \mathrm{H}, \mathrm{d}$, $J=7.1 \mathrm{~Hz}), 7.68(1 \mathrm{H}, \mathrm{d}, J=9.0 \mathrm{~Hz}), 7.86(1 \mathrm{H}, \mathrm{d}, J=8.0 \mathrm{~Hz}), 11.66(1 \mathrm{H}, \mathrm{s})$, $12.78(1 \mathrm{H}, \mathrm{brs}) .{ }^{13} \mathrm{C}-\mathrm{NMR}\left(100 \mathrm{MHz}\right.$, DMSO- $\left.d_{6}\right) \delta: 29.43(\mathrm{~s}), 61.41(\mathrm{~s})$ $112.55(\mathrm{~s}), 115.19(\mathrm{~s}), 117.62(\mathrm{~s}), 119.19(\mathrm{~s}), 119.38(\mathrm{~s}), 123.59$ (s), 123.71 (s), $127.89(\mathrm{~s}), 128.31$ (s), 129.52 (s), 129.61 (s), 130.68 (s), 132.50 (s), 135.77 (s), 147.84 (s), 155.06 (s). ESI-MS $m / z$ : +ESI 306 (M+1), -ESI $304(\mathrm{M}-1)$. HR-ESI-MS $\mathrm{m} / \mathrm{z}: 328.1061$ (Calcd for $\mathrm{C}_{18} \mathrm{H}_{15} \mathrm{~N}_{3} \mathrm{O}_{2} \mathrm{Na}$ : $328.1062)$.

3-[3-(2-Aminoethyl)-1 $\boldsymbol{H}$-indol-2-yl]quinoxalin-2(1H)-one, $\quad 2 c \quad{ }^{1} \mathrm{H}$ NMR $\left(400 \mathrm{MHz}\right.$, DMSO- $\left.d_{6}\right) \delta: 3.17(2 \mathrm{H}, \mathrm{t}, J=7.6 \mathrm{~Hz}), 3.58(2 \mathrm{H}, \mathrm{t}$, $J=7.6 \mathrm{~Hz}), 7.11(1 \mathrm{H}, \mathrm{t}, J=8.1 \mathrm{~Hz}), 7.24(1 \mathrm{H}, \mathrm{t}, J=8.1 \mathrm{~Hz}), 7.29-7.40(2 \mathrm{H}$, m), $7.53(1 \mathrm{H}, \mathrm{t}, J=7.3 \mathrm{~Hz}), 7.69(1 \mathrm{H}, \mathrm{d}, J=8.1 \mathrm{~Hz}), 7.73(1 \mathrm{H}, \mathrm{d}, J=8.1 \mathrm{~Hz})$, $8.03(1 \mathrm{H}, \mathrm{d}, J=7.3 \mathrm{~Hz}), 11.86(1 \mathrm{H}, \mathrm{br} \mathrm{s}) .{ }^{13} \mathrm{C}-\mathrm{NMR}\left(100 \mathrm{MHz}\right.$, DMSO- $\left.d_{6}\right) \delta$ : $24.26(\mathrm{~s}), 112.90(\mathrm{~s}), 115.03$ (s), 118.83 (s), 119.60 (s), 123.55 (s), 123.84 (s), $127.35(\mathrm{~s}), 128.67(\mathrm{~s}), 129.85(\mathrm{~s}), 130.04(\mathrm{~s}), 131.08(\mathrm{~s}), 132.55(\mathrm{~s})$, 135.78 (s), 147.45 (s), 155.27 (s). ESI-MS m/z: +ESI 305 (M+1), -ESI 303 (M-1). HR-ESI-MS $m / z: 305.1423$ (Calcd for $\mathrm{C}_{18} \mathrm{H}_{17} \mathrm{~N}_{4} \mathrm{O}: 305.1402$ ).

2-[2-(3-Oxo-3,4-dihydroquinoxalin-2-yl)- $1 H$-indol-3-yl]acetamide, 2d ${ }^{1} \mathrm{H}-\mathrm{NMR}\left(400 \mathrm{MHz}, \mathrm{DMSO}-d_{6}\right) \delta: 4.14(2 \mathrm{H}, \mathrm{s}), 6.80(1 \mathrm{H}, \mathrm{br} \mathrm{s}), 7.07(1 \mathrm{H}, \mathrm{t}$, $J=7.6 \mathrm{~Hz}), 7.22(1 \mathrm{H}, \mathrm{t}, J=7.6 \mathrm{~Hz}), 7.27(1 \mathrm{H}, \mathrm{br} \mathrm{s}), 7.34-7.38(2 \mathrm{H}, \mathrm{m}), 7.52$ $(1 \mathrm{H}, \mathrm{dt}, J=1.5,8.0 \mathrm{~Hz}), 7.66(1 \mathrm{H}, \mathrm{d}, J=7.6 \mathrm{~Hz}), 7.68(1 \mathrm{H}, \mathrm{d}, J=7.6 \mathrm{~Hz})$, $7.87(1 \mathrm{H}, \mathrm{d}, J=8.0 \mathrm{~Hz}), 11.74(1 \mathrm{H}, \mathrm{s}) .{ }^{13} \mathrm{C}-\mathrm{NMR}\left(100 \mathrm{MHz}\right.$, DMSO- $\left.d_{6}\right) \delta$ : $33.23(\mathrm{~s}), 112.63(\mathrm{~s}), 114.53$ (s), 115.31 (s), $119.36(\mathrm{~s}), 119.51(\mathrm{~s}), 123.67$ (s), $127.97(\mathrm{~s}), 128.17$ (s), 129.71 (s), 130.00 (s), 130.87 (s), 132.39 (s), 135.79 (s), 147.83 (s), 155.15 (s), 172.90 (s). ESI-MS m/z: +ESI $319(\mathrm{M}+1)$, -ESI $317(\mathrm{M}-1)$. HR-ESI-MS m/z: 341.1022 (Calcd for $\left.\mathrm{C}_{18} \mathrm{H}_{14} \mathrm{~N}_{4} \mathrm{O}_{2} \mathrm{Na}: 341.1014\right)$.

3-[2-(3-Oxo-3,4-dihydroquinoxalin-2-yl)-1 H-indol-3-yl]propanoate, $2 \mathrm{e}$ ${ }^{1} \mathrm{H}-\mathrm{NMR}\left(400 \mathrm{MHz}\right.$, DMSO- $\left.d_{6}\right) \delta: 2.75(2 \mathrm{H}, \mathrm{t}, J=7.8 \mathrm{~Hz}), 3.54(2 \mathrm{H}, \mathrm{t}$, $J=7.8 \mathrm{~Hz}), 3.59(3 \mathrm{H}, \mathrm{s}), 7.07(1 \mathrm{H}, \mathrm{t}, J=7.8 \mathrm{~Hz}), 7.21(1 \mathrm{H}, \mathrm{t}, J=7.8 \mathrm{~Hz})$, $7.36-7.39(2 \mathrm{H}, \mathrm{m}), 7.53(1 \mathrm{H}, \mathrm{t}, J=6.8 \mathrm{~Hz}), 7.66(1 \mathrm{H}, \mathrm{d}, J=7.8 \mathrm{~Hz}), 7.68$ $(1 \mathrm{H}, \mathrm{d}, J=7.8 \mathrm{~Hz}), 7.76(1 \mathrm{H}, \mathrm{d}, J=6.8 \mathrm{~Hz}), 11.74(1 \mathrm{H}, \mathrm{s}), 12.83(1 \mathrm{H}, \mathrm{br} \mathrm{s})$ ${ }^{13} \mathrm{C}-\mathrm{NMR}\left(100 \mathrm{MHz}\right.$, DMSO- $\left.d_{6}\right) \delta: 34.16(\mathrm{~s}), 51.13(\mathrm{~s}), 112.71(\mathrm{~s}), 115.31$ (s), $119.02(\mathrm{~s}), 119.09(\mathrm{~s}), 119.37(\mathrm{~s}), 123.70(\mathrm{~s}), 123.79(\mathrm{~s}), 127.09(\mathrm{~s})$, $128.09(\mathrm{~s}), 129.33(\mathrm{~s}), 129.65(\mathrm{~s}), 130.69(\mathrm{~s}), 132.58(\mathrm{~s}), 135.71(\mathrm{~s}), 147.61$ (s), 155.13 (s), 173.27 (s). ESI-MS $m / z$ : +ESI $348(\mathrm{M}+1),-$ ESI 346 (M-1). HR-ESI-MS $m / z$ : 370.1162 (Calcd for $\mathrm{C}_{20} \mathrm{H}_{17} \mathrm{~N}_{3} \mathrm{O}_{3} \mathrm{Na}$ : 370.1168).

3-(Indol-3-yl)quinoxalin-2(1H)-one, $\mathbf{2 h}^{7}{ }^{1}{ }^{1} \mathrm{H}-\mathrm{NMR}$ (400 MHz, DMSO$\left.d_{6}\right) \delta: 7.21-7.40(4 \mathrm{H}, \mathrm{m}), 7.42(1 \mathrm{H}, \mathrm{t}, J=7.0 \mathrm{~Hz}), 7.50(1 \mathrm{H}, \mathrm{m}), 7.87(1 \mathrm{H}$, d, $J=8.0 \mathrm{~Hz}), 8.86(1 \mathrm{H}, \mathrm{m}), 8.93(1 \mathrm{H}, \mathrm{d}, J=2.9 \mathrm{~Hz}), 11.77(1 \mathrm{H}, \mathrm{s}), 12.38$ $(1 \mathrm{H}, \mathrm{s}) .{ }^{13} \mathrm{C}-\mathrm{NMR}\left(100 \mathrm{MHz}, \mathrm{DMSO}-d_{6}\right) \delta: 111.26(\mathrm{~s}), 111.82(\mathrm{~s}), 114.88$ (s), $120.93(\mathrm{~s}), 122.49(\mathrm{~s}), 122.91(\mathrm{~s}), 123.18(\mathrm{~s}), 126.15(\mathrm{~s}), 127.54(\mathrm{~s})$, 1127.93 (s), 130.13 (s), 132.60 (s), 133.01 (s), 136.23 (s), 151.93 (s), 154.35 (s). ESI-MS $m / z$ : +ESI $262(\mathrm{M}+1),-$ ESI $260(\mathrm{M}-1)$.

Alternative synthesis of 2a. Methyl 1-(tert-Butoxycarbonyl)-3-methyl$\mathbf{1 H}$-indole-2-glyoxylate, 4 To a solution of $3(3.00 \mathrm{~g}, 12.9 \mathrm{mmol})$ in DCM $(50 \mathrm{ml})$ was added dropwise tert-butyl lithium $(1.57 \mathrm{~mol} / 1$ in pentane, $9.0 \mathrm{ml}$, $14.2 \mathrm{mmol}$ ) during $20 \mathrm{~min}$ period at $-78^{\circ} \mathrm{C}$, and then the reaction mixture was allowed to stir for $1 \mathrm{~h}$ at $-78^{\circ} \mathrm{C}$. A solution of dimethyl oxalate $(3.92 \mathrm{~g}$, $33.2 \mathrm{mmol})$ in DCM $(25 \mathrm{ml})$ was added to the stirring reaction mixture at $-78^{\circ} \mathrm{C}$, and then the reaction mixture was stirred at $-78^{\circ} \mathrm{C}$ for $1 \mathrm{~h}$. The resulting reaction mixture was quenched with saturated $\mathrm{NH}_{4} \mathrm{Cl}$ aq., and the 
water phase was extracted with $\mathrm{Et}_{2} \mathrm{O}$. The combined organic phase was washed with brine, and then dried over $\mathrm{Na}_{2} \mathrm{SO}_{4}$. After removing the organic solvent in vacuo, the residue was purified by flash column chromatography on silica gel (hexane/AcOEt, 20/1 $\rightarrow 4 / 1$ ), and then re-crystallized from $\mathrm{Et}_{2} \mathrm{O} /$ hexane to give $4(0.86 \mathrm{~g}, 2.71 \mathrm{mmol})$ as a yellow solid. Yield: $21 \%{ }^{1} \mathrm{H}-$ NMR $\left(400 \mathrm{MHz}, \mathrm{CDCl}_{3}\right) \delta: 1.64(9 \mathrm{H}, \mathrm{s}), 2.43(3 \mathrm{H}, \mathrm{s}), 3.88(3 \mathrm{H}, \mathrm{s}), 7.32$ $(1 \mathrm{H}, \mathrm{t}, J=8.0 \mathrm{~Hz}), 7.48(1 \mathrm{H}, \mathrm{dd}, J=8.0,8.5 \mathrm{~Hz}), 7.64(1 \mathrm{H}, \mathrm{d}, J=8.0 \mathrm{~Hz})$ $8.00(1 \mathrm{H}, \mathrm{d}, J=8.5 \mathrm{~Hz})$. ESI-MS $m / z$ : +ESI $340(\mathrm{M}+\mathrm{Na}),-\mathrm{ESI} 318(\mathrm{M}+1)$.

2a: A mixture of $4(502 \mathrm{mg}, 1.57 \mathrm{mmol})$ and 1,2-phenylenediamine $(188 \mathrm{mg}, 1.74 \mathrm{mmol})$ in $\mathrm{MeOH}(5.0 \mathrm{ml})$ was refluxed for $13 \mathrm{~h}$, and then TFA $(0.5 \mathrm{ml})$ was added to the reaction mixture, and the reaction mixture was refluxed for $1 \mathrm{~h}$. After cooling, the precipitated product was collected by filtration and washed with $\mathrm{Et}_{2} \mathrm{O}$ to give $2 \mathrm{a}(124 \mathrm{mg}, 0.45 \mathrm{mmol})$ as a yellow solid Yield: $28.6 \%$, Comparison of ${ }^{1} \mathrm{H}-,{ }^{13} \mathrm{C}-\mathrm{NMR}$ and MS spectrum data with those of $\mathbf{2 a}$, described previously, showed them to be identical.

5-(Benzyloxy)-1H-indole-3-carbaldehyde, 6 To a mixture of imidazole $(1.52 \mathrm{~g}, 22.4 \mathrm{mmol})$ and acetic anhydride $(9.0 \mathrm{ml})$ was added dropwise a solution of $5(5.00 \mathrm{~g}, 22.4 \mathrm{mmol})$ in acetic anhydride $(14.5 \mathrm{ml})$ during a $30 \mathrm{~min}$ period at $130{ }^{\circ} \mathrm{C}$. The reaction mixture was allowed to stir for $1 \mathrm{~h}$ at $130^{\circ} \mathrm{C}$ A solution of $\mathrm{NaOH}(4.20 \mathrm{~g}, 105 \mathrm{mmol})$ in $\mathrm{EtOH}(80 \mathrm{ml})$ and $\mathrm{H}_{2} \mathrm{O}(20 \mathrm{ml})$ was added carefully to the reaction mixture, and then the solution was refluxed for $1 \mathrm{~h}$. After cooling the resulting reaction mixture to room temperature, the solution was acidified with $1 \mathrm{~mol} / 1 \mathrm{HCl}$ aq. The deposited precipitate was collected by filtration to give $6(4.98 \mathrm{~g}, 19.8 \mathrm{mmol})$ as a yellow solid. Then, after removing the organic solvent of the filtrate in vacuo, the residue was purified by flash column chromatography on silica gel (hexane/AcOEt, $1 / 1)$ to give $6(114 \mathrm{mg}, 0.45 \mathrm{mmol})$ as a yellow solid. Total yield: $91 \%$. ${ }^{1} \mathrm{H}-\mathrm{NMR}\left(200 \mathrm{MHz}, \mathrm{CDCl}_{3}\right) \delta: 5.14(2 \mathrm{H}, \mathrm{s}), 7.00(1 \mathrm{H}$, dd, $J=2.5,8.9 \mathrm{~Hz}), 7.31-7.51(6 \mathrm{H}, \mathrm{m}), 7.79(1 \mathrm{H}, \mathrm{d}, J=3.2 \mathrm{~Hz}), 7.88(1 \mathrm{H}, \mathrm{d}$, $J=2.5 \mathrm{~Hz}), 9.98(1 \mathrm{H}, \mathrm{s}), 11.04(1 \mathrm{H}$, br s)

5-(Benzyloxy)-3-methyl-1H-indole, 7 To a mixture of 6 (5.0 g, 19.9 $\mathrm{mmol}$ ) and $10 \% \mathrm{Pd}-\mathrm{C}$ (wet type, $2.5 \mathrm{~g}$ ) in 2-propanol $(250 \mathrm{ml})$ was carefully added portionwise sodium borohydride $(12 \mathrm{~g}, 317 \mathrm{mmol})$. The reaction mixture was then refluxed for $3 \mathrm{~h}$. After removal of the precipitates by filtration, the filtrate was concentrated in vacuo. Water was added to the residue, and the water phase was then extracted with $\mathrm{Et}_{2} \mathrm{O}$. The combined organic phase was washed with brine and dried over $\mathrm{Na}_{2} \mathrm{SO}_{4}$. After removing the organic solvent in vacuo, the residue was purified by flash column chromatography on silica gel (hexane/AcOEt, 3/1) to give 7 (3.95 g, $16.7 \mathrm{mmol})$ as a yellow solid. Yield: $84 \%$. ${ }^{1} \mathrm{H}-\mathrm{NMR}\left(200 \mathrm{MHz}, \mathrm{CDCl}_{3}\right) \delta$ : $2.29(3 \mathrm{H}, \mathrm{s}), 5.12(2 \mathrm{H}, \mathrm{s}), 6.90-7.52(9 \mathrm{H}, \mathrm{m})$.

tert-Butyl 5-Hydroxy-3-methyl-1H-indole-1-carboxylate, 8 To a mixture of 7 (10.9 g, $46.1 \mathrm{mmol})$, 4-dimethylaminopyridine $(2.70 \mathrm{~g}, 22.1 \mathrm{mmol})$ and triethylamine $(7.2 \mathrm{ml}, 51.6 \mathrm{mmol})$ in $\mathrm{CH}_{3} \mathrm{CN}(200 \mathrm{ml})$ was added di-tertbutyl dicarbonate $(12.0 \mathrm{~g}, 55.5 \mathrm{mmol})$ at room temperature, and the reaction mixture was allowed to stir for $5 \mathrm{~h}$ at room temperature. After removing the organic solvent of the resulting reaction mixture, the residue was purified by flash column chromatography on silica gel (hexane/AcOEt, 10/1) to give tert-butyl 5-(benzyloxy)-3-methyl- $1 H$-indole-1-carboxylate (15.2 g, $45.1 \mathrm{mmol}$ ) as a viscous oil. A solution of tert-butyl 5-(benzyloxy)-3methyl-1H-indole-1-carboxylate $(\mathrm{ca} .13 .0 \mathrm{~g}, 38.5 \mathrm{mmol})$ and $5 \% \mathrm{Pd}-\mathrm{C}$ (dry type, $2.8 \mathrm{~g}$ ) in AcOEt $(400 \mathrm{ml})$ was then stirred for $5 \mathrm{~h}$ at room temperature under hydrogen. After removing the precipitates by filtration, the filtrate was concentrated in vacuo. The residue was purified by flash column chromatography on silica gel (hexane/AcOEt, 9/1) to give $8(9.27 \mathrm{~g}, 37.5 \mathrm{mmol}$ ) as a yellow solid. 2 steps yield: $95 \%$. ${ }^{1} \mathrm{H}-\mathrm{NMR}\left(200 \mathrm{MHz}, \mathrm{CDCl}_{3}\right) \delta: 1.64(9 \mathrm{H}$, s), $2.20(3 \mathrm{H}, \mathrm{s}), 4.67(1 \mathrm{H}, \mathrm{s}), 6.82(1 \mathrm{H}, \mathrm{dd}, J=2.5,8.7 \mathrm{~Hz}), 6.90(1 \mathrm{H}, \mathrm{d}$, $J=2.5 \mathrm{~Hz}), 7.32(1 \mathrm{H}, \mathrm{s}), 7.95(1 \mathrm{H}, \mathrm{d}, J=8.7 \mathrm{~Hz})$.

6-Fluoro-3-[3-methyl-5-(2-piperidin-1-ylethoxy)-1H-indol-2-yl]-
quinoxalin-2(1H)-one, 9 To a solution of $8(2.30 \mathrm{~g}, 9.30 \mathrm{mmol})$ in DMF $(46 \mathrm{ml})$ and $\mathrm{Cs}_{2} \mathrm{CO}_{3}(9.10 \mathrm{~g}, 27.9 \mathrm{mmol})$ was added 1-(2-chloroethyl)piperidine hydrochloride $(2.60 \mathrm{~g}, 14.1 \mathrm{mmol})$ at room temperature, and then the reaction mixture was stirred at $60^{\circ} \mathrm{C}$ for $5 \mathrm{~h}$. Water was added to the resulting reaction mixture, and the water phase was extracted with AcOEt. The combined organic phase was washed with brine and dried over $\mathrm{Na}_{2} \mathrm{SO}_{4}$. After removing the organic solvent in vacuo, the residue was dissolved in DCE $(100 \mathrm{ml})$. To the above solution were added 6-fluoroquinoxaline-2-one $(1.85 \mathrm{~g}, 11.4 \mathrm{mmol})$ and TFA $(8 \mathrm{ml})$ at room temperature, and the reaction mixture was refluxed for $0.5 \mathrm{~h}$. Saturated $\mathrm{NaHCO}_{3}$ aq was added to the resulting reaction mixture, and the water phase was extracted with AcOEt. The combined organic phase was washed with brine and dried over $\mathrm{Na}_{2} \mathrm{SO}_{4}$. After removing of organic solvent in vacuo, the residue was purified by flash column chromatography on silica gel $\left(\mathrm{CHCl}_{3} / \mathrm{MeOH}, 30 / 1\right)$, and then re-crystallized from $\mathrm{CHCl}_{3} /$ hexane $/ \mathrm{MeOH}$ to give 9 ( $1.92 \mathrm{~g}$, $4.58 \mathrm{mmol})$ as a yellow solid. 2 steps yield: $49 \%$. ${ }^{1} \mathrm{H}-\mathrm{NMR}(400 \mathrm{MHz}$, DMSO- $\left.d_{6}\right) \delta: 1.38-1.55(6 \mathrm{H}, \mathrm{m}), 2.49-2.51(4 \mathrm{H}, \mathrm{m}), 2.73(2 \mathrm{H}, \mathrm{t}$, $J=6.0 \mathrm{~Hz}), 2.74(3 \mathrm{H}, \mathrm{s}), 4.11(2 \mathrm{H}, \mathrm{t}, J=6.0 \mathrm{~Hz}), 6.87(1 \mathrm{H}, \mathrm{dd}, J=2.2$, $8.8 \mathrm{~Hz}), 7.10(1 \mathrm{H}, \mathrm{s}), 7.36-7.40(2 \mathrm{H}, \mathrm{m}), 7.53(1 \mathrm{H}, \mathrm{d}, J=8.8 \mathrm{~Hz}), 7.63(1 \mathrm{H}$ dd, $J=2.7,9.5 \mathrm{~Hz}), 11.58(1 \mathrm{H}, \mathrm{s}), 12.79(1 \mathrm{H}, \mathrm{brs}),{ }^{13} \mathrm{C}-\mathrm{NMR}(100 \mathrm{MHz}$ DMSO- $\left.d_{6}\right) \delta: 11.84(\mathrm{~s}), 23.85(\mathrm{~s}), 25.49(\mathrm{~s}), 54.39(\mathrm{~s}), 57.55(\mathrm{~s}), 65.84(\mathrm{~s})$, $100.64(\mathrm{~s}), 112.86\left(\mathrm{~d}, J_{\mathrm{F}}=22.3 \mathrm{~Hz}\right), 113.60(\mathrm{~s}), 115.97$ (s), $116.25(\mathrm{~d}$, $\left.J_{\mathrm{F}}=9.1 \mathrm{~Hz}\right), 116.48(\mathrm{~s}), 117.10\left(\mathrm{~d}, J_{\mathrm{F}}=12.4 \mathrm{~Hz}\right), 127.33(\mathrm{~s}), 128.12(\mathrm{~s})$ $129.46(\mathrm{~s}), 131.48(\mathrm{~s}), 132.99\left(\mathrm{~d}, J_{\mathrm{F}}=12.4 \mathrm{~Hz}\right), 149.14(\mathrm{~s}), 152.67$ (s), 154.90 (s), $158.23\left(\mathrm{~d}, J_{\mathrm{F}}=240 \mathrm{~Hz}\right)$. ESI-MS $m / z$ : +ESI $421(\mathrm{M}+1),-$ ESI 419 (M-1). HR-ESI-MS m/z: 421.2049 (Calcd for $\mathrm{C}_{24} \mathrm{H}_{26} \mathrm{~N}_{4} \mathrm{O}_{2} \mathrm{~F}: 421.2040$ ).

\section{References and Notes}

1) Ladouceur G. H., Bear B., Bi C., Brittelli D. R., Burke M. J., Chen G., Cook J., Dumas J., Sibley R., Turner M. R., WO 2004043950 (2004).

2) Inhibitory effect of $\mathbf{9}$ toward the VEGF-induced proliferation of human glomerular endothelium cells in vitro $\left[\mathrm{IC}_{50}(\mu \mathrm{mol} / 1)=0.04\right]$. Inhibitory effect of 9 toward the VEGF-induced auto-phosphorylation with human umbilical vein endothelial cells in vitro $\left[\mathrm{IC}_{50}\right.$ $(\mu \mathrm{mol} / 1)=0.02]$. Inhibitory effect of the derivative 9 on VEGF-induced dye leakage in rat skin ( 7 week-old male Wistar rats were used in this study) [70\% against control at $25 \mathrm{mg} / \mathrm{kg}$ p.o.].

3) Aoki K., Obata T., Yamazaki Y., Mori Y., Hirokawa H., Koseki J., Hattori T., Niitsu K., Takeda S., Aburada M., Miyamoto K., Chem. Pharm. Bull., 55, 255-267 (2007).

4) For review on typical example of TFA-promoted Friedel-Crafts type reaction, see: Fei L., Yong-Jun C., Yong S., Li L., Dong W., Synlett, 8, 1160-1164 (2003).

5) Similar indolenine and/or direct pathway as in the mechanism of Pictet-Spengler reaction may be engaged in this TFA-promoted coupling process of 3-substituted indoles with quinoxalin-2-ones. For review on discussion about this mechanism, see: Enrique L. L., Marcela A., Andrea B. J. B., Teodoro S. K., ARKIVOC. Issue in Honor of Prof. Rosa Lederkremer, (xii), 98-153 (2005).

6) Although it is not yet ascertained about the details of the oxidization mechanism, it seems that it is probably based on auto-oxidation. For review on example of similar reaction, see: ref. 7 .

7) Chupakhin O. N., Sidorov E. O., Postovskii I. Y., Khimiya Geterotsiklicheskikh Soedinenii, 10, 1433-1434 (1975).

8) The TFA-catalyzed coupling of 3-methyl-1-(phenylsulfonyl)- $1 H$-indole with quinoxaline-2-one was failed in our result.

9) Jan B., Lars R., Birger S., Tetrahedron, 36, 2505-2511 (1980).

10) Heacock R. A., Hutzinger O., Can. J. Chem., 42, 514-521 (1964). 